Pteridines

Vol. 3 , pp. $5-10$

\title{
Review
}

\section{Molecular Basis for the Phenotypic Diversity of Phenylketonuria}

\author{
F. Güttler
}

The John F. Kennedy Institute, Gl. Landevej 7, DK-2600 Glostrup, Denmark

The Alois Niederwieser Memorial Lecture presented at the 5th International Conference on Pteridines and Related Biogenic Amines and Folates at Palm Cove, 4879 Queensland, Australia

(Received March 1992)

\section{Introduction}

Phenylketonuria (PKU) is an autosomal recessive inherited deficiency of hepatic phenylalanine hydroxylase (phenylalanine 4-monooxygenase: EC 1.14.16.1; L-phenylalanine, tetrahydropteridine: oxygen oxidoreductase) which catalyzes the hydroxylation of phenylalanine to tyrosine. When untreated the disease causes mental retardation at a variable degree (1) and all neonates are screened for hyperphenylalaninemia.

A switch in the screening procedure from a test that relies on detection of phenylpyruvate in the urine to a simple and sensitive method for the determination of phenylalanine (phe) in blood (2) converted what had been thought to be a simple clinical and biochemical entity into a spectrum of disorders showing hyperphenylalaninemia (3). The discovery of hyperphenylalaninemic conditions which to a variable degree biochemically mimic the condition described by Følling in 1934 (4) has demanded increased knowledge of the various types of defects in the metabolism of phe (e.g. phenylalanine hydroxylase (PAH) deficiency, tetrahydrobiopterin $\left(\mathrm{BH}_{4}\right)$ deficiency) because of the ultimate prognosis of each type in relation to the need for optimal treatment (5).

Abbreviations: phenylalanine hydroxylase, $\mathrm{PAH}$; phenylketonuria, PKU; hyperphenylalaninemia, HPA; polymerase chain reaction, PCR; allele-specific oligonucleotide, ASO; phenylalanine, phe.
The different phenotypes of phenylalanine hydroxylase deficiency

Within the first decade of screening for neonatal hyperphenylalaninemia it became clear that the PAH deficiency trait is phenotypically heterogeneous (6). There are two well-defined clinical and biochemical entities of phenylalanine PAH deficiency; a) phenylketonuria $(\mathrm{PKU})$ with pretreatment blood phe levels $>1200 \mu \mathrm{mol} / 1,<1 \%$ of normal enzyme activity and a low tolerance for phe (7) and, b) persistent benign hyperphenylalaninemia (non-PKU HPA) with phe levels persistently below $600 \mu \mathrm{mol} / 1$ on a normal diet and with $5-10 \%$ of normal enzyme activity (8). In addition to these well-defined phenotypes there are intermediate "variant" or "mild" forms of PKU with pretreatment blood phe levels of $600-1200 \mu \mathrm{mol} / \mathrm{l}$, $1 \%-5 \%$ of normal enzyme activity, and a relaxed phenylalanine tolerance (Fig. 1). Recommended concentrations of serum phe to be maintained during therapy are $160-300 \mu \mathrm{mol} / \mathrm{l}(9,10,11)$. Some centers intitiate dietary treatment at phe levels above 1200 $\mu \mathrm{mol} / 1(10,12,13)$, others start treatment at phe lcvels above $900 \mu \mathrm{mol} / 1(14,15)$, and some start dietary treatment when blood phe levels exceed $600 \mu \mathrm{mol} / 1$ $(9,16)$.

A classification of the different phenotypes of $\mathrm{PAH}$ deficiency based on the dietary phe tolerance of the child was proposed in $1980(8)$. The phe tolerance is related to the parental phenotype as detcrmined by the tyrosine response to a phe loading test (Table 1) (17). The most obvious explanation would be different mutant alleles $(8,18)$. 


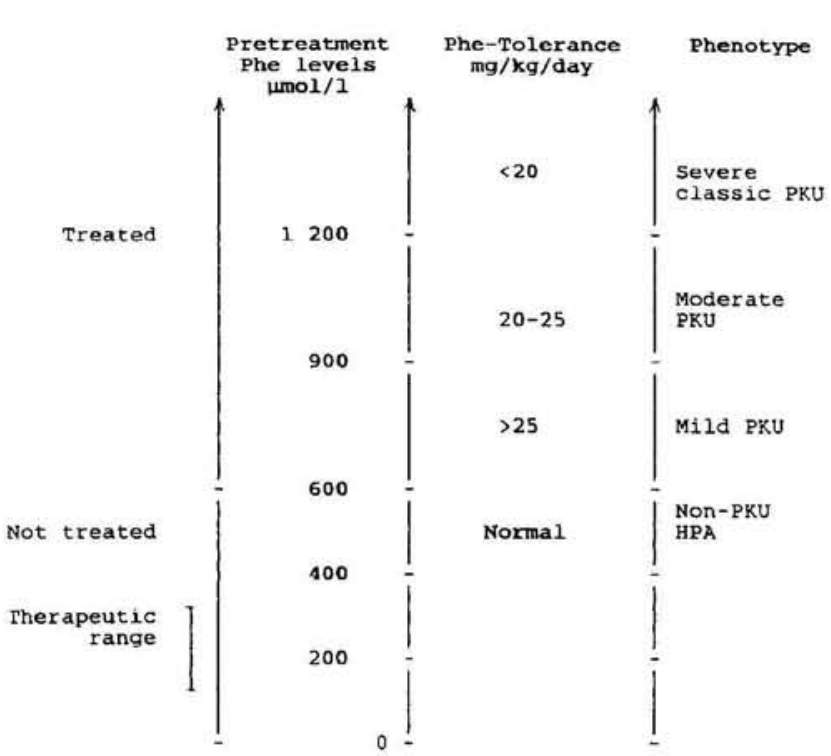

Figure 1. The different phenotypes of phenylalanine hydroxylase deficiency classified according to pretreatment phenylalanine levels and the amount of phenylalanine tolerated in $\mathrm{mg}$ per $\mathrm{kg}$ body weight per day at 5 years of age. Most centers start treatment, when phenylalanine levels exceed $600 \mu \mathrm{mol} / \mathrm{l}$ and patients with these levels are classified as having one of the various phenotypes of phenylketonuria (PKU). Individuals with phenylalanine levels below $600 \mu \mathrm{mol} / 1$ show a normal development without treatment and have the non-PKU hyperphenylalaninemia (HPA) phenotype.

Table 1. Relation between the parental phenotype and the combined phenotype of their affected offspring.

\begin{tabular}{cccc}
\hline $\begin{array}{l}\text { Phenotype } \\
\text { of parent* }\end{array}$ & $0-2$ & $>2-6$ & $>6$ \\
\hline $0-2$ & Classical & Classical & Mild \\
& PKU & PKU & PKU \\
$>2-6$ & Classical & Mild & Non-PKU \\
& PKU & PKU & HPA \\
$>6$ & Mild & Non-PKU & Non-PKU \\
& PKU & HPA & HPA \\
\hline
\end{tabular}

* Phenotype of parent: rate of tyrosine formation times maximum value of serum tyrosine divided with the maximum value of serum phenylalanine observed after a load of $0.1 \mathrm{~g}$ phenylalanine $/ \mathrm{kg}$ body weight.

The association between RFLP halotypes and clinical phenotypes

A partial cDNA of the PAH gene was cloned in 1982 (19) and the first results of segregation analyses published in 1983 (Fig. 2) (20, 21). Haplotype studies were initiated in $1984(22,23,24)$ and the relationship between the haplotypes of the two inherited mutant alleles and the phenotype of the offspring was demonstrated in 1987 (Table 2) (25), and later confirmed (26).

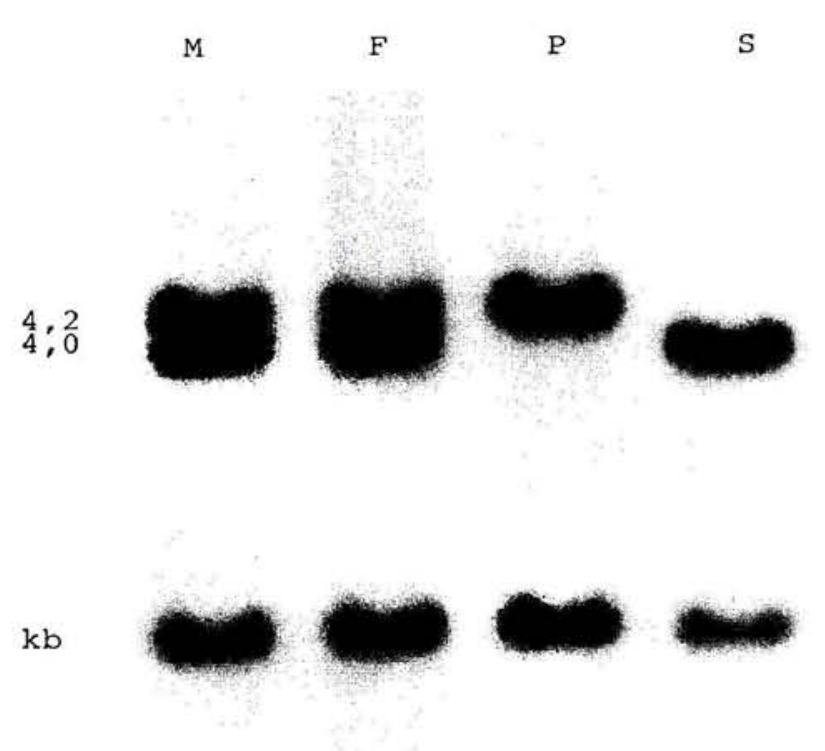

Figure 2. The segregation of the PKU alleles in a Danish family demonstrated by restriction fragment length polymorphisms at the phenylalanine hydroxylase locus obtained by the restriction enzyme HindIII and the phPAH 247 cDNA probe. The PKUallele segregates with the $4.2 \mathrm{~kb}$ fragment from the mother $(\mathrm{M})$ and the father $(\mathrm{F})$ to the PKU-child $(\mathrm{P})$. The normal phenylalanine hydroxylase allele segregates with the $4.0 \mathrm{~kb}$ fragment from the parents to the unaffected sibling (S), who has inherited the two normal chromosomes of the family.

Table 2. Haplotype of PKU alleles correlated to phenotypes in 74 Danish patients.

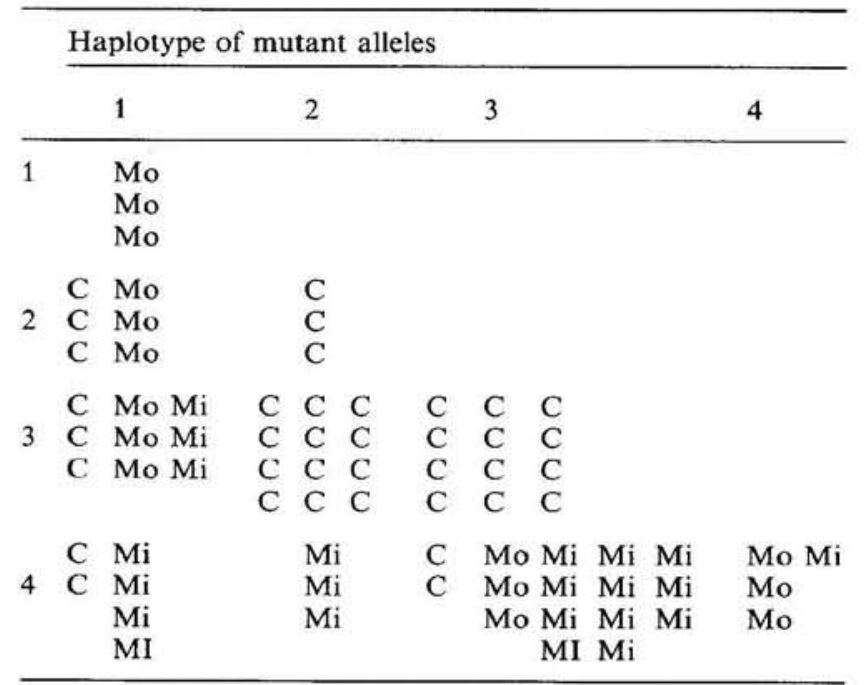

C: Classic PKU; $<20 \mathrm{mg}$ phe $/ \mathrm{kg} /$ day

Mo: Moderate PKU, 20-25 mg phe/kg/day

Mi: Mild PKU; $>25 \mathrm{mg}$ phe $/ \mathrm{kg} /$ day

tolerated at five years of age

\section{PKU-mutations}

The correlation between RFLP haplotypes and clinical phenotypes (Table 2) (25) formed a strategy for sequencing the first two PKU-alleles in Danish chil- 
dren with severe classic PKU (27). The deficient PAH activity of an allele associated with haplotype 3 was discovered to be a $\mathrm{G} \rightarrow \mathrm{A}$ mutation in the obligatory donor splice site in intron 12 (IVS-12). The result is that the coding sequence of exon 12 is spliced off during the transcription (28). The allele responsible for severe classic PKU in Denmark and associated with haplotype 2 was discovered to be a $\mathrm{C} \rightarrow \mathrm{T}$ transition in codon 408 of exon 12, which results in a substitution of arginine with tryptophan. Expression studies showed no detectable enzyme activity (29).

During the past four years an increasing number of mutations in the PAH gene have been discovered. In 198911 mutations were described (26), and $31 \mathrm{mu}-$ tations were known in November 1990 (30). In November 1991 the number of known mutations in the $\mathrm{PAH}$ gene may have reached more than 50 . However, many mutations are rare and some are common only within certain ethnic groups or populations. The codon 408 mutation is common in Eastern European countries $(31,32)$ and is probably of Slavic origin. The originally discovered IVS-12 mutation may have a founding population in Nothern Europe, perhaps in Jutland of Denmark (33). A substitution in intron 10 is prevalent among PKU patients in Turkey and Bulgaria and the distribution suggests a Middle Eastern origin. A secondary dissemination of this allele may have occurred during the Roman colonization, and the later extent of the Ottoman Empire (34).

Relation of mutation genotype to biochemical and clinical phenotype

In vitro expression studies revealed a spectrum of $\mathrm{PAH}$ activities from $0 \%$ to $50 \%$ of normal activity depending on the mutant allele examined (7). In accordance with the in vitro studies there is a relationship between the pretreatment blood phe levels (the biochemical phenotype) and the amount of phe tolerated in the diet to keep blood phe at nearly normal levels (Fig. 3). The result is a relation between the

\section{Phenylketonuria mutations and the associated}

\section{phenotypes in 59 Danish patients}

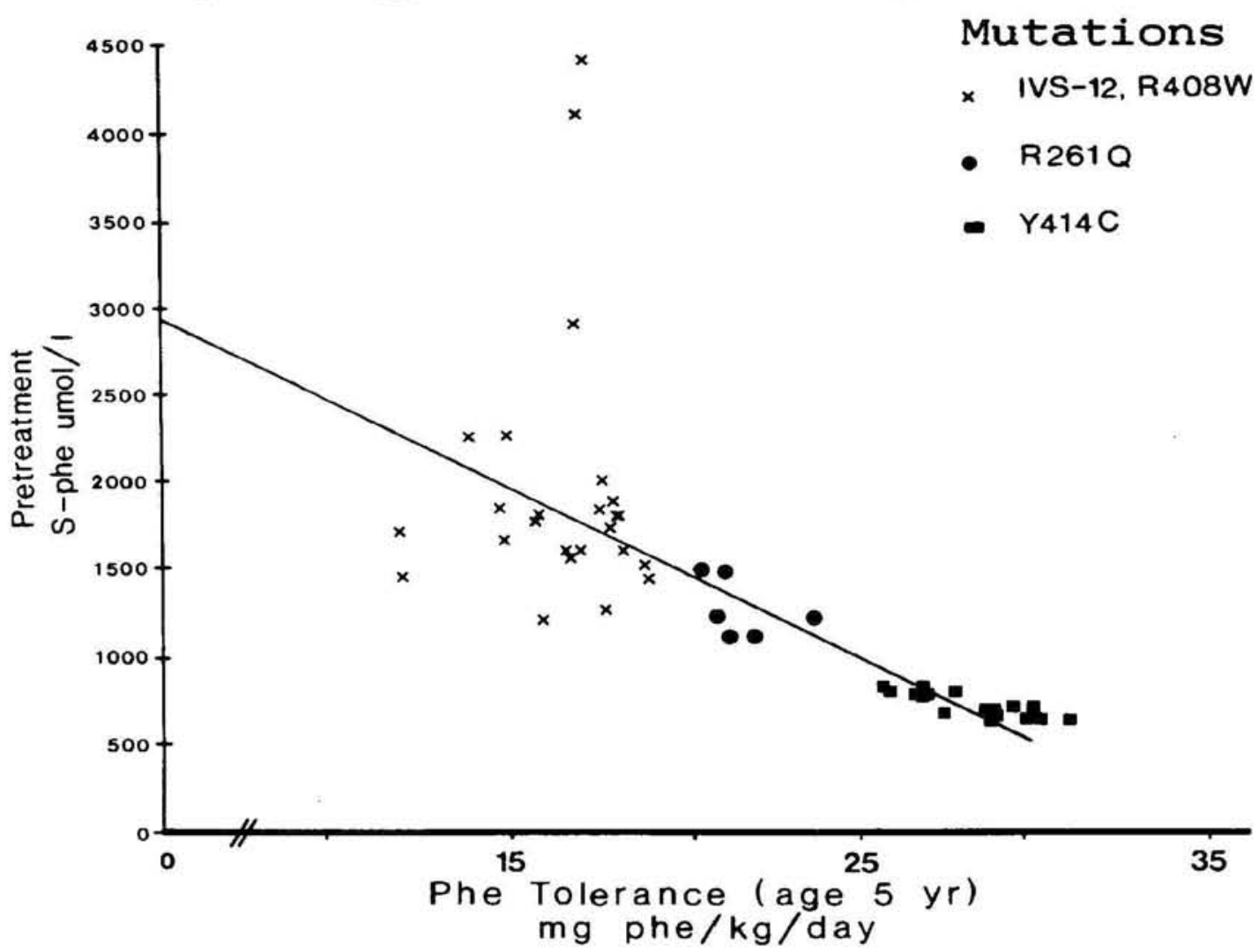

Figure 3. The relation between the inherited mutant alleles and the pretreatment blood phenylalanine levels (the biochemical phenotype) and the amount of phenylalanine tolerated in the diet to keep blood phenylalanine at nearly normal levels (clinical phenotype). The mutant alleles of the patients were detected by allele-specific oligonucleotide probing after PCR amplification of the appropriate exons of the PAH gene. 
Table 3. Correlation between mutation genotype and different phenotypes of PKU and non-PKU hyperphenylalaninemia in 82 Danish patients.

\begin{tabular}{|c|c|c|c|c|}
\hline Mutation & $\begin{array}{l}\text { R408W } \\
\text { IVS-10 } \\
\text { IVS-12 }\end{array}$ & $\begin{array}{l}\text { R261Q } \\
\text { L348V }\end{array}$ & $\mathrm{Y} 414 \mathrm{C}$ & $\begin{array}{l}\text { I306W } \\
\text { D415N }\end{array}$ \\
\hline $\begin{array}{l}\text { R408W } \\
\text { IVS-10 } \\
\text { IVS-12 }\end{array}$ & $\begin{array}{l}\text { Severe } \\
\text { classic PKU } \\
\mathrm{N}=39\end{array}$ & $\begin{array}{l}\text { Moderate } \\
\text { PKU } \\
\mathrm{N}=5\end{array}$ & $\begin{array}{l}\text { Mild } \\
\text { PKU } \\
\mathrm{N}=22\end{array}$ & $\begin{array}{l}\text { Non-PKU } \\
\mathrm{HPA} \\
\mathrm{N}=4\end{array}$ \\
\hline $\begin{array}{l}\text { R158Q } \\
\text { E280K } \\
\text { P281L }\end{array}$ & $\begin{array}{l}\text { Severe } \\
\text { classic PKU } \\
N=7\end{array}$ & $\begin{array}{l}\text { Moderate } \\
\text { PKU } \\
\mathrm{N}=1\end{array}$ & $\begin{array}{l}\text { Mild } \\
\text { PKU } \\
\mathrm{N}=1\end{array}$ & \\
\hline $\begin{array}{l}\text { R261Q } \\
\text { L348V }\end{array}$ & & $\begin{array}{l}\text { Mild } \\
\mathrm{PKU} \\
\mathrm{N}=2\end{array}$ & & \\
\hline $\mathrm{Y} 414 \mathrm{C}$ & & & $\begin{array}{l}\text { Mild } \\
\text { PKU } \\
\mathrm{N}=2\end{array}$ & \\
\hline
\end{tabular}

inherited two mutant alleles and the clinical phenotype of the patient (Table 3 ). This observation also explains the previously described association between the heterozygous phenotypes of the parents as determined by the tyrosine response to a phe load, and the phenotype of their affected offspring (Table 1).

The genotype-phenotype relation and "danger levels" for mental deficiency

Since the institution of treatment for PKU, the blood level at which dietary restriction of phe intake should be initiated has been debated. A survey of 43 untreated mentally retarded institutionalized patients with PKU revealed that $80 \%$ of the patients had two mutations (IVS-12 and R408W), which are common among patients with classic PKU. However, $20 \%$ of the patients had mutations (Y414C, R158Q) which cause moderate or mild PKU and blood phe levels of $600-1200 \mu \mathrm{mol} / 1$ (35). The occurrence of mental retardation in patients with serum phe concentrations below $1200 \mu \mathrm{mol} / 1$ (36) and the reported cases of 16 normally intelligent (IQ > 90) pcople with PKU (37) may have some bearing on the hypothesis that mild PKU may cause a reduction in IQ points which is fatal for some (IQ without PKU added 100), but not for others (IQ without PKU added 140).

So, we believe that we must treat all infants appearing to have PAH deficiency with serum phe levels above $600 \mu \mathrm{mol} / \mathrm{l}$, as these levels of phe may cause mental deficiency. The recent knowledge about the mutations associated with this phe level $(7,35)$ enables us to distinguish neonates with this biochemical phenotype of the disease by ASO probing of PCR-amplified DNA from the blood spots used for neonatal screen- ing of hyperphenylalaninemia. Children with this type of PAH deficiency have a relaxed phe tolerance and need less rigid dietary restrictions of phe intake (8).

The molecular basis for non-PKU hyperphenylalaninemia

The question whether dietary management should be initiated in all neonates with PAH deficiency appeared when it was recognized that children with serum phe levels below $600 \mu \mathrm{mol} / \mathrm{l}$ appear to show a normal intellectual and behavioural development without treatment $(38,39)$. These children have the non-PKU HPA phenotype.

Initiation of dietary therapy soon after birth has important psychological and social implications (40). So, it is imperative as early as possible to distinguish newborn children who require a phenylalanine restricted diet, from those who have the non-PKU HPA phenotype. Recently, Avigad et al. (41) observed that in six of 27 families the non-PKU HPA phenotype resulted from compound heterozygosity for haplotypes associated with a PKU allele and an allele, which might carry a mutation with a milder effect. By ASO probing of PCR-amplified DNA from 17 children with non-PKU HPA we have observed that 12 patients had inherited one of the common mutations associated with PKU and six patients had a mutation found in patients with severe classic PKU (R408W or IVS-12) (42). We identified two new mutations in four of these six patients. It was further demonstrated that the identified mutations (D415N in exon 12 and L306V in exon 9 of the PAH gene) had less impact on the heterozyogte's ability to hydroxylate phenylalanine to tyrosine compared to the parent carrying the classic PKU mutation (42). The combined effect of these mutations in their affected offspring is either no detectable increase or a slight increase in serum tyrosine within the first hour after a phenylalanine load (43) which explains the non-PKU HPA phenotype at the molecular lcvel. The observation that PKU mutations combined with less deleterious mutations cause the non-PKU HPA phenotpye, and that particular mutation-RFLF haplotype combinations are associated with this phenotype enables us for the first time to distinguish hyperphenylalaninemic neonates who need dietary therapy, from those who do not.

\section{Future studies}

A possible relationship between mutation genotype and the ultimate prognosis of the individual with PKU, as well as the question to what extent the mutation genotype of a PKU female and the inherited 
mutant allele of her child may influence the outcome following a planned pregnancy, are new challenges for future studies.

\section{Acknowledgements}

This study was supported by grants from the Danish Medical Research Council (nos. 12-7414, 12-0782, and 12-9292), The Danish Biotechnological Research and Developmental programme 1991-95 (grant no. 5.18.03), The Danish Health Insurance Foundation (no. $\mathrm{H} 11 / 210-89, \mathrm{H} 11 / 282$, and $\mathrm{H} \mathrm{11/257-91),} \mathrm{The}$ Foundation of 1870 , The Novo Foundation, Frantz Hoffmann's Memorial Fund, Emil and Inger Hertz' Fund, Frode Nygaard's Fund, P. Carl Petersen's Fund, and Stenild and Else Hjorth's Fund.

\section{References}

1. Güttler, F. \& Lou, H. (1990) in: Inborn Metabolic Diseases: Diagnosis and Treatment (Fernandes, J., Saudubray, J-M. \& Tada, K., eds.) pp. 161-174, Springer Verlag, Berlin, Heidelberg.

2. Guthrie, R. \& Susi, A. (1963) A simple phenylalanine method for detecting phenylketonuria in large populations of newborn infants. Pediatrics $32,338-343$.

3. Scriver, C. R., Kaufman, S. \& Woo, S. C. L. (1989) in: The Metabolic Basis of Inherited Disease, 6th ed. (Scriver, C. R., Beaudet, A., Sly, W. \& Valle, D., eds.) pp. $495-546$, McGraw-Hill, New York.

4. Følling, A. (1934) Über Ausscheidung von Phenylbrenztraubensäure in den Harn als Stoffwechselanomalie in Verbindung mit Imbezillität. Ztschr. Physiol. Chem. 227, 169176.

5. Smith, I. (1985) in: Genetic and Metabolic Disease (Lloyd, J. K. \& Scriver, C. R., eds.) pp. 166-209, Butterworths, London (Butterworth's International Medical Reviews, Pediatrics 5 )

6. Güttler, F. (1984) Phenylketonuria: 50 years since Følling's discovery and still expanding our clinical and biochemical knowledge. Acta Paediatr. Scand. 73, 705-716.

7. Okano, Y., Eisensmith, R. C., Güttler, F., Lichter-Konecki, U., Konecki, D. S., Trefz, F. K., Dasovich, M., Wang, T., Henriksen, K., Lou, H. \& Woo, S. L. C. (1991) Molecular basis of phenotypic heterogeneity in phenylketonuria. $\mathrm{N}$. Engl. J Med. 324, 1232-1238.

8. Güttler, F. (1980) Hyperphenylalaninemia: diagnosis and classification of the various types of phenylalanine hydrox ylase deficiency in childhood. Acta Paediatr. Scand. (suppl.) $280,1-80$.

9. Bickel, H. (1970) Phenylalaninaemia or classical phenylketonuria (PKU)? Neuropädiatrie 1, 379-382.

10. Koch, R., Blask ovics, M., Wenz, E., Fishler, K. \& Schaeffler, G. (1974) in: Heritable Disorders of Amino Acid Metabolism: Patterns of Clinical Expression and Genetic Variation (Nyhan, W. L., ed.) pp. 109-140, John Wiley \& Sons, Inc., New York, London, Sydney.

11. Smith, I., Francis, D. E. M., Clayton, B. E. \& Wolff, O. H. (1975) Comparison of an amino acid mixture and protein hydrolysate in treatment of infants with phenylketonuria. Arch. Dis. Childh. 50, 864-870.

12. Menkes, J. H. \& Holtzman, N. A. (1970) Neonatal hyperphenylalaninemia: A differential diagnosis. Neuropädiatric $1,434-446$
13. Blaskovics, M. E., Schaeffler, G. E. \& Hack, S. (1974) Phenylalaninaemia. Differential diagnosis. Arch. Dis. Childh. 49, 835-843.

14. Francis, D. E. M. (1974) Diets for Sick Children, 3rd ed. Blackwell Scientific Publications, Oxford.

15. Clayton, B. E. (1975) in: The Treatment of Inherited Metabolic Disease (Raine, D. N., ed.) pp. 1-32, MTP, Lancaster, England.

16. Güttler, F. \& Wamberg, E. (1977 b) On indications for treatment of the hyperphenylalaninemic neonate. Acta. Paed. Scand. 66, 339-344.

17. Güttler, F. \& Hansen, G. (1977) Different phenotypes for phenylalanine hydroxylase deficiency. Ann. Clin. Biochem. 14, $124-134$.

18. Woolf, L. I. (1971) in: Phenylketonuria, and some other Inborn Errors of Amino Acid Metabolism (Bickel, H., Hudson, F. P. \& Woolf, L. E., eds.) pp. 103-109, Georg Thieme Verlag, Stuttgart.

19. Robson, K. J. H., Chandra, T., MacGillivray, R. T. A. \& Woo, S. L. C. (1982) Polysome immunoprecipitation of phenylalanine hydroxylase mRNA from rat liver and cloning of its cDNA. Proc. Natl. Acad. Sci. USA 79, 47014705 .

20. Güttler, F., Woo, S. L. C. \& Robson, K. J. H. (1984) The possibility for prenatal diagnosis of PKU by linkage analyscs bascd on phenylalanine hydroxylase locus specific DNA-polymorphisms. J. Inher. Metab. Dis. 7, $139-140$.

21. Woo, S. L. C., Lidsky, A. S., Güttler, F., Chandra, T. \& Robson, K. H. H. (1983) Cloned human phenylalanine hydroxylase gene permits prenatal diagnosis and carrier detection of classical phenylketonuria. Nature $306,151-$ 155.

22. Lidsky, A. S., Ledley, F. D., DiLella, A. G., Kwok, S. C. M., Daiger, S. P., Robson, K. J. H. \& Woo, S. L. C. (1985) Extensive restriction site polymorphism at the human phenylalanine hydroxylase locus and application in prenatal diagnosis of phenylketonuria. Am. J. Hum. Genet. 37, $324-327$.

23. Güttler, F. \& Woo, S. L. C. (1985) in: Recent Progress in the Understanding, Recognition and Management of Inherited Disease of Amino Acid Metabolism (Bickel, H. \& Wachtel, U., eds.) pp. $18-36$, Georg Thieme Verlag, Stuttgart.

24. Chakraborty, R. Lidsky, A. S., Daiger, S. P., Güttler, F., Sullivan, S., DiLella, A. G. \& Woo, S. L. C. (1987) Polymorphic DNA haplotypes at the human phenylalanine hydroxylase locus and their relationship with phenylketonuria. Hum. Genet. 76, 40-46.

25. Güttler, F., Ledley, F. D., Lidsky, A. S., DiLella, A. G., Sullivan, S. E. \& Woo, S. L. C. (1987) Correlation between polymorphic DNA haplotypes at phenylalanine hydroxylase locus and clinical phenotypes of phenylketonuria. J. Pediatr. $110,68-71$.

26. Cotton, R. G. H. (1990) Heterogeneity of phenylketonuria at the clinical, protein, and DNA levels. J. Inher. Metab. Dis. $13,739-750$.

27. Güttler, F., DiLella, A. G., Ledley, F. D., Lidsky, A. S., Kwok, S. C. M., Marvit, J. \& Woo, S. L. C. (1987) Molecular biology of phenylketonuria. Eur. J. Pediatr. 146, 5-11.

28. DiLella, A. G., Marvit, J., Lidsky, A. S., Güttler, F. \& Woo, S. L. C. (1986) Tight linkage between a splicing mutation and a specific DNA haplotype in phenylketonuria. Nature $322,799-803$.

29. DiLella, A. G., Marvit, J., Brayton, K. \& Woo, S. L. C. (1987) An amino-acid substitution involved in phenylketonuria is in linkage disequilibrium with DNA haplotype 2. Nature $327,333-336$.

30. Scriver, C. R. (1991) Phenylketonuria - genotypes and phenotypes (editorial). N. Engl. J. Med. 324, 1280-1281.

31. Jaruzelska, J., Henriksen, K. F., Güttler, F., Riess, O. et al. (1991) The predominant mutant allele in Polish families with phenylketonuria is associated with haplotype 2 . $\mathrm{Hu}-$ man. Genet. 86, 247-250. 
32. Kalaydjieva, L., Dworniczak, B., Kucinskas, V., Yurgeliavicius, V., Kuncrt, E. \& Horst, J. (1991) Geographical distribution gradients of the major PKU mutations and the linked haplotypes. Hum. Genet. 86, 411-413.

33. Güttler, F., Guldberg, P. \& Henriksen, K. (1992) in: Neonatal Screening in the Nineties (Wilcken, B., ed.) Byrton Lawrence Printers, Sydney (in press).

34. Dasovich, M., Konecki, D., Licher-Konecki, U., Eisensmith, R. C., Güttler, F., Naughton, E., Mullins, C., Gionannini, M., Riva, E. \& Woo, S. L. C. (1991) Molecular characterization of a PKU allele prevalent in southern Europe and Ireland. Som. Cell and Mol. Genet. (in press).

35. Güttler, F., Guldberg, P. \& Henriksen, K. F. (1992) Mutation genotype of mentally retarded patients with phenylketonuria. Brain Dys. (in press).

36. Güttler, F. \& Wamberg, E. (1977) Fasting serum phenylalanine in untreated institutionalized patients with phenylketonuria. J. Ment. Defic. Res. 21, 55-62.

37. Perry, T. L., Hansen, S., Tischler, B., Richards, F. M. \& Sokol, M. (1973) Unrecognized adult phenylketonuria. Implications for obstetrics and psychiatry. N. Engl. J. Med. $289,395-398$
38. Woolf, L. I., Ounsted, C., Lee, D., Humphrey, M., Cheshire, N. M. \& Steed, G. R. (1961) Atypical phenylketonuria in sisters with normal offspring. Lancet $i i, 464-465$.

39. Levy, H. L., Shih, V. E., Karolkewicz, V., French, W. A. Carr, J. R., Cass, V., Kennedy, J. L. \& Mac Cready, R. A (1971) Persistent mild hyperphenylalaninemia in the untreated state. A prospective study. N. Engl. J. Med. 285 . $424-429$.

40. Mikkelsen, I., Scharling, E., Svendson, F. U. \& Wamberg, E. (1974) The influence of dietary treatment on the psychosocial conditions in families with phenylketonuric children. Näringsforskning $18,78-86$.

41. Avigad, S., Kleiman, S., Weinstein, M. Cohen, B, E. Schwartz, G., Woo, S. L. C. \& Shiloh, Y. (1991) Compound heterozygosity in non-phenylketonuria hyperphenylalaninemia: The contribution of mutations for classical phenylketonuria. Am. J. Hum. Genet. 49, 393-399.

42. Economou-Petersen, E., Henriksen, K. F., Guldberg, P. \& Güttler, F. (1991) The molecular basis for non-phenylketonuria hyperphenylalaninemia. Genomics (submitted).

43. Güttler, F. \& Hansen, G. (1977) Serum tyrosine within the first hour after an oral load of phenylalanine. Scand. J. Clin. Lab. Invest. 37, 717-722. 